Sains Malaysiana 48(1)(2019): 69-73

http://dx.doi.org/10.17576/jsm-2019-4801-08

\title{
Short-Term Cytotoxicity of Zinc Oxide Nanoparticles on Chlorella vulgaris
}

(Ketoksikan Jangka Pendek Zarah Nano Zink Oksida ke atas Chlorella vulgaris)

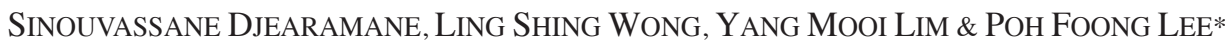

\section{ABSTRACT}

Zinc oxide nanoparticles ( $\mathrm{ZnO} N P s)$ are widely used in industrial and personal care products. The use of these nanoparticles (NPS) has created residues that contaminate the environment, thus cytotoxicity studies of the NPs in biological system is required. Most of the recent cytotoxicity studies has however focused on long-term exposure of the NPs to the biological system. In this study, the cytotoxicity effects of short-term exposure of ZnO NPs to Chlorella vulgaris are reported. The algal cells were exposed to 10, 50, 100, 150, and $200 \mathrm{mg} / \mathrm{L}$ of ZnO NPs for $12 \mathrm{~h}$. The toxicity effects of ZnO NPs were then determined through the changes in fluorescence emission of chlorophyll, algal biomass and the viable cell count. The results showed a decrease in the chlorophyll content, algal biomass and cell viability after treatment with $\mathrm{ZnO}$ NPs as compared with control. Through this study, the effects of ZnO NPs to C. vulgaris were confirmed. The significant responses of the algal cells to ZnO NPs in a short duration of exposure reflect the potential of the algal cells to be used as bioindicators of ZnO NPs in the aquatic environment.

Keywords: Algal cells; Chlorella vulgaris; short-term cytotoxicity; zinc oxide nanoparticles

\section{ABSTRACT}

Zarah nano zink oksida (ZnO NP) digunakan secara meluas dalam produk industri dan penjagaan peribadi. Penggunaan zarah nano tersebut telah menghasilkan residu yang membawa pencemaran kepada alam sekitar. Oleh itu, kajian kesan kesitotoksikan ZnO NP terhadap sistem biologi amat diperlukan. Namun, kajian kesan kesitotoksikan pada masa ini lebih tertumpu kepada kesan jangka panjang terhadap sistem biologi. Oleh itu, dalam kajian ini, kesan kesitotoksikan jangka masa pendek ZnO NP terhadap Chlorella vulgaris telah dilaporkan. Sel alga tersebut telah didedahkan kepada ZnO NP dengan kepekatan yang berbeza (10, 50, 100, 150 dan 200 mg/L) untuk jangka masa sehingga 12 jam. Kesan kesitotoksikan ZnO NP pada sel alga telah dipantau melalui perubahan pendarfluoran klorofil, perubahan biojisim dan kemandirian sel alga.Pendedahan sel alga kepada ZnO NP telah mengakibatkan pengurangan kandungan klorofil, biojisim dan kemandirian sel alga. Melalui kajian ini, kesan ZnO NP terhadap C. vulgaris telah dikenal pasti. Keupayaan C. vulgaris bertindak balas dengan ZnO NP dalam jangka masa yang pendek menampilkan potensi alga tersebut digunakan sebagai petunjuk biologi untuk penilaian ketoksikan ZnO NP dalam persekitaran akuatik.

Kata kunci: Chlorella vulgaris; kesitotoksikan jangka pendek; sel alga; zarah nano zink oksida

\section{INTRODUCTION}

The field of nanotechnology is expanding rapidly and the usage of nanoparticles in industry brings great impact to the society, economy and environment ( $\mathrm{Ji}$ et al. 2011). Zinc oxide nanoparticles represent a type of nanoparticle most widely used in consumer products due to its unique characteristics. For instance, the presence of $\mathrm{ZnO}$ NPs provides a clear transparent appearance that allows them to be used in skin care products (Popov et al. 2005). $\mathrm{ZnO}$ NPs are also commonly used in the electronics, rubber and food industries (Dastjerdi \& Montazer 2010; Song et al. 2010) due to their chemical stability, adsorption ability and antimicrobial property (Osmond \& Mccall 2010). However, use of ZnO NPs may bring negative impact to the environment and to human health (Adams et al. 2006; Moore 2006; Wiesner et al. 2006; Zhao \& Castranova 2011; Zhou et al. 2014). Previous cytotoxicity studies of $\mathrm{ZnO}$ NPs using fresh water microalgae $C$. vulgaris were mostly focused on long-term exposure to theses NPs (Chen et al. 2012; Suman et al. 2015; Zhou et al. 2014). However, no study has been conducted to study the shortterm cytotoxicity of ZnO NPs on $C$. vulgaris. Thus, the present study involves cytotoxicity assessment based on short-term exposure of ZnO NPs to C. vulgaris.

\section{MATERIALS AND METHODS}

\section{PREPARATION OF ALGAL CULTURE AND SOLUTION OF ZnO NPs}

Fresh water microalgae $C$. vulgaris was obtained from the Culture Collection of Algae and Protozoa, United Kingdom. The algal cells were cultured with Bold Basal Medium (BBM, Sigma-Aldrich, Malaysia) at room temperature $\left(22 \pm 1^{\circ} \mathrm{C}\right)$ with light and dark conditions and maintained for 16 and $8 \mathrm{~h}$, respectively. Continuous 
agitation was carried out at 120 revolutions per minute using orbital shaker (A3446, Smith, Malaysia). The growth pattern of the algal cells was determined based on cell count, biomass and chlorophyll content.

$\mathrm{ZnO}$ NPs with the particle size of 40 - $50 \mathrm{~nm}$ were purchased from Zhejiang Hongsheng Material Technology Co., China. A stock solution of $400 \mathrm{mg} / \mathrm{L} \mathrm{ZnO}$ NPs was prepared with BBM. The colloidal solution was sonicated for $30 \mathrm{~min}$ before the exposure test.

\section{EXPOSURE OF ALGAL CELLS TO ZnO NPs}

BBM with different concentrations of ZnO NPs (200, $150,100,50$, and $10 \mathrm{mg} / \mathrm{L}$ ) were prepared through serial dilutions from the stock solution. $C$. vulgaris cells from a day-3 culture with approximate cell density of $1 \times 10^{6}$ cells/mL were exposed to the different concentrations of $\mathrm{ZnO}$ NPs, respectively, for $12 \mathrm{~h}$. Negative control consisted of cells cultured in BBM without ZnO NPs. All exposure tests were conducted in triplicates.

\section{DETERMINATION OF CELL VIABILITY AND ALGAL BIOMASS}

The number of viable $C$. vulgaris cells was determined using hemocytometer (Neubauer, Marienfeld, Germany) after the cells were exposed to $\mathrm{ZnO}$ NPs for 2, 4, 8, and 12 $\mathrm{h}$, respectively. The cells without any distortion in shape and size and with intact membrane were identified as viable cells. The percentage of growth inhibition of $C$. vulgaris was calculated using (1) (Li et al. 2016).

$$
\% \mathrm{I}=(\mu \mathrm{C}-\mu \mathrm{T}) / \mu \mathrm{C} \times 100 .
$$

where $\% \mathrm{I}$ is the percentage of growth inhibition or cell death; $\mu \mathrm{C}$ is the mean value of viable cells in negative control; and $\mu \mathrm{T}$ is the mean value of viable cells in treatment.

The algal biomass was determined using spectrophotometer (GeneQuant 1300, GE, United States of America) at $\lambda=680 \mathrm{~nm}$. BBM without algal cells was used as blank and the suspension of $\mathrm{ZnO}$ NPs without algal cells was used as positive control. The biomass yield in the treated samples was calculated by subtracting the absorbance value of positive control from the treated samples in order to take into account interference from $\mathrm{ZnO}$ NPs at $680 \lambda$ (Sadiq et al. 2011). The percentage of reduction in biomass yield (\%Iy) was calculated using (2).

$$
\% \mathrm{Iy}=(\mathrm{bC}-\mathrm{bT}) / \mathrm{bC} \times 100
$$

where \% Iy is the percentage of reduction in biomass yield; bC is the biomass in negative control; and bT is the biomass in treatment.

\section{DETERMINATION OF CHLOROPHYLL FLUORESCENCE EMISSION}

Inhibition of photosynthetic activity by $\mathrm{ZnO}$ NPs was estimated by measuring fluorescence emission of chlorophyll using a fluorometer (Promega Glomax Multi Jr., Promega, United States of America). The excitation and emission wavelengths were set at $\lambda=430 \mathrm{~nm}$ and $\lambda=663$ $\mathrm{nm}$, respectively. The percentage of change in the intensity of chlorophyll fluorescence emission was calculated using Equation 3 (Shing et al. 2012).

$$
\% \mathrm{fE}=\mathrm{fC}-\mathrm{fT} / \mathrm{fC} \times 100 .
$$

where $\% \mathrm{fE}$ is the percentage of change in chlorophyll fluorescence emission; $\mathrm{fC}$ is the fluorescence emission from negative control; and $\mathrm{fT}$ is the fluorescence emission from treatment.

\section{RESULTS AND DISCUSSION}

\section{ALGAL GROWTH INHIBITION}

The number of viable cell was affected by the presence of $\mathrm{ZnO}$ NPs. The growth inhibition in negative control was fixed as $0 \%$ for the exposure tests. The number of viable cells decreased when the duration of exposure and the concentration of $\mathrm{ZnO}$ NPs were increased (Figure 1). Suman et al. (2015) reported a similar trend on cytotoxicity effects of $\mathrm{ZnO}$ NPs on C. vulgaris. Nano-sized $\mathrm{ZnO}$ particles which are easily absorbed through cell surfaces, inhibited the growth of $C$. vulgaris and decreased the number of viable cells. Under microscopic examination, the cell membrane remained intact in untreated algal cells (Figure 2(A)), whereas cell rupture and aggregation were observed in cells treated with ZnO NPs (Figure 2(B)). The ruptured cells appear colorless due to the loss of chlorophyll through membrane damage. The aggregation of algal cells may be due to the secretion of algal exudates, for example exopolysaccharides (EPS) reported to be used in the protective mechanism during oxidative stress caused by the ZnO NPs on algal cells (Bhuvaneshwari et al. 2015; Brayner et al. 2010; Miao et al. 2009).

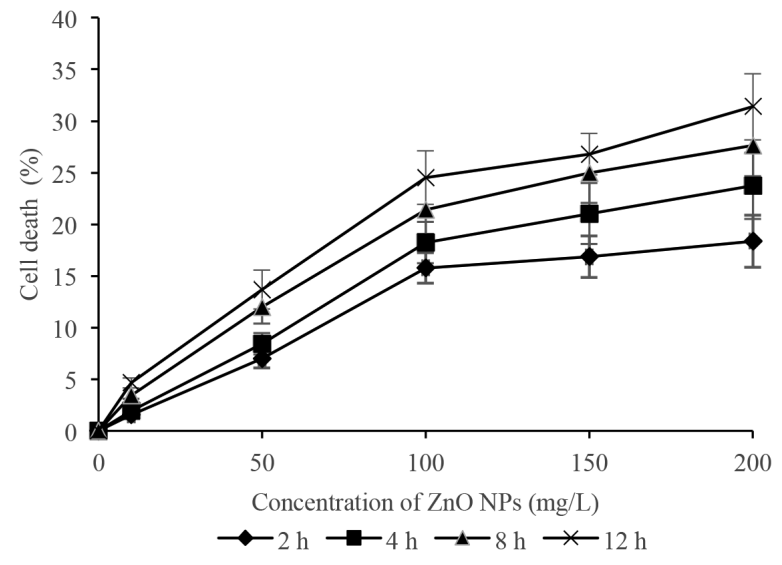

FIGURE 1. Percentage of cell death against different concentrations of $\mathrm{ZnO}$ NPs with the exposure of $\mathrm{ZnO}$ NPs from 2 to $12 \mathrm{~h}$ 

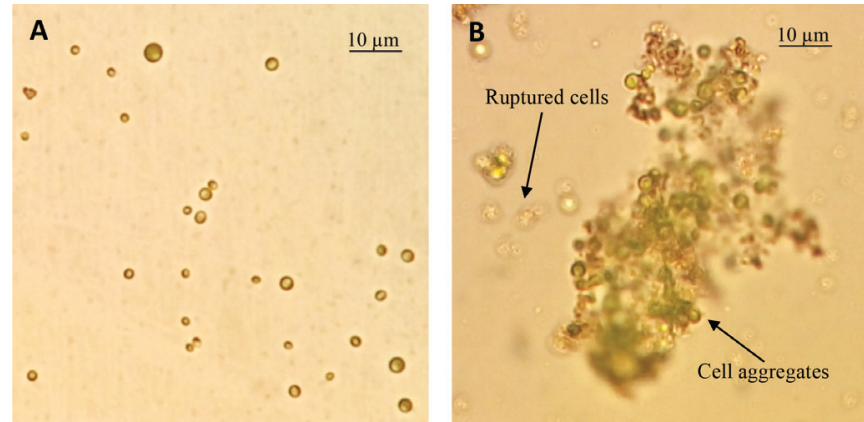

FIGURE 2. Light microscopic image of $C$. vulgaris cells treated with ZnO NPs. Algal cells in the absence of NP (A) and in the presence of ZnO NPs $(200 \mathrm{mg} / \mathrm{L})$ at $12 \mathrm{~h}$,

(B) showing cell rupture and cell aggregates under $100 \times$ magnification

The algal biomass yield was reduced due to the presence of $\mathrm{ZnO}$ NPs (Figure 3). A concentration and time dependent inhibitory effects of $\mathrm{ZnO}$ NPs on $C$. vulgaris were observed with the highest inhibition in biomass yield $(26.34 \pm 3.87 \%)$ at the concentration of $200 \mathrm{mg} / \mathrm{L}$ following $12 \mathrm{~h}$ of exposure. The results are in agreement with the toxicity effects caused by the presence of aluminum oxide nanoparticles on Chlorella sp. (Sadiq et al. 2011).

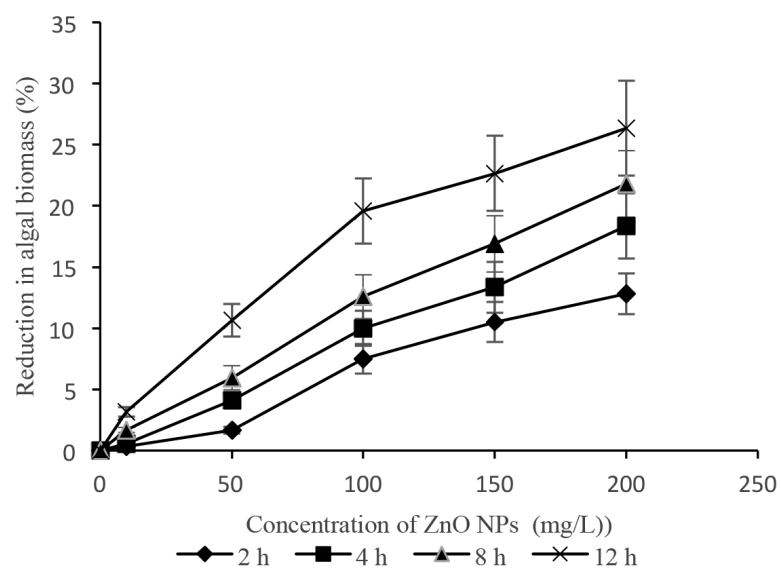

FIGURE 3 . The effect of different concentrations of $\mathrm{ZnO}$ NPs to the production of biomass from 2 to $12 \mathrm{~h}$

\section{REDUCTION IN CHOROPHYLL CONTENT}

The change on chlorophyll content can be used to assess cytotoxicity effect on algal cells (Barhoumi \& Dewez 2013; Iswarya et al. 2015). The fluorescence property of chlorophyll has proven to be a useful tool for cytotoxicity evaluation (Shing et al. 2012; Tang et al. 2013). In this study, the fluorescence emission of chlorophyll decreased with the increasing concentrations of $\mathrm{ZnO}$ NPs and the duration of exposure to the NPs (Figure 4).

Similar to the cell viability and algal biomass, $\mathrm{ZnO}$ NPs exhibited a dosage and time-dependent inhibition on chlorophyll fluorescence emission from $C$. vulgaris cells. At $12 \mathrm{~h}$ of inhibition, chlorophyll emission was reduced from $4.48 \pm 0.69 \%$ to $25.95 \pm 2.54 \%$ as the concentration

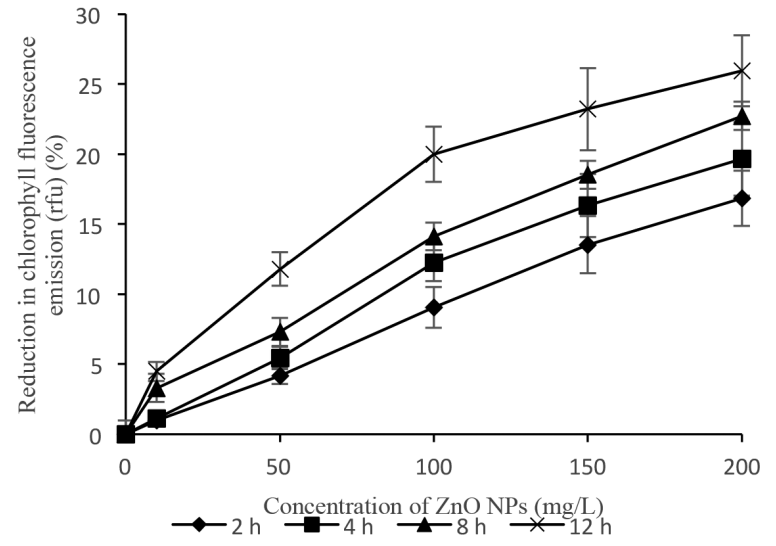

FIGURE 4. Percentage of reduction in chlorophyll content of algal cells treated with different concentrations of $\mathrm{ZnO}$ NPs from 2 to $12 \mathrm{~h}$

of the NPs increased from 10 to $200 \mathrm{mg} / \mathrm{L}$. Likewise, with the concentration of $200 \mathrm{mg} / \mathrm{L}, \mathrm{ZnO}$ NPs caused a timedependent inhibition with the reduction in chlorophyll emission from $16.83 \pm 1.98 \%$ at the exposure time of 2 $\mathrm{h}$ to $25.95 \pm 2.54 \%$ at $12 \mathrm{~h}$.

The reduction in chlorophyll content may be caused by the inhibitory reaction of the NPs on photosynthetic electron transport chain (Barhoumi \& Dewez 2013; Sadiq et al. 2011; Xiaoxiao et al. 2012). Entrapment of ZnO NPs by the algal cells caused direct shading effect and thus decreased the light availability and disturbed the energy transduction process. This induced oxidative stress in the cells and affected their growth and chlorophyll content (Iswarya et al. 2015). The decline in chlorophyll content is further explained by the production of free radicals inducing the formation of reactive oxygen species, leading to impairment of the photosynthetic system II activity (Tang et al. 2013).

Findings from the present study showed both dosage- and time-dependent inhibitions by ZnO NPs on cell viability, biomass and chlorophyll fluorescence emission of $C$. vulgaris (Figure 5). The presence of $\mathrm{ZnO}$ NPs substantially reduced the viability of $C$. vulgaris cells, biomass and chlorophyll fluorescence emission. 

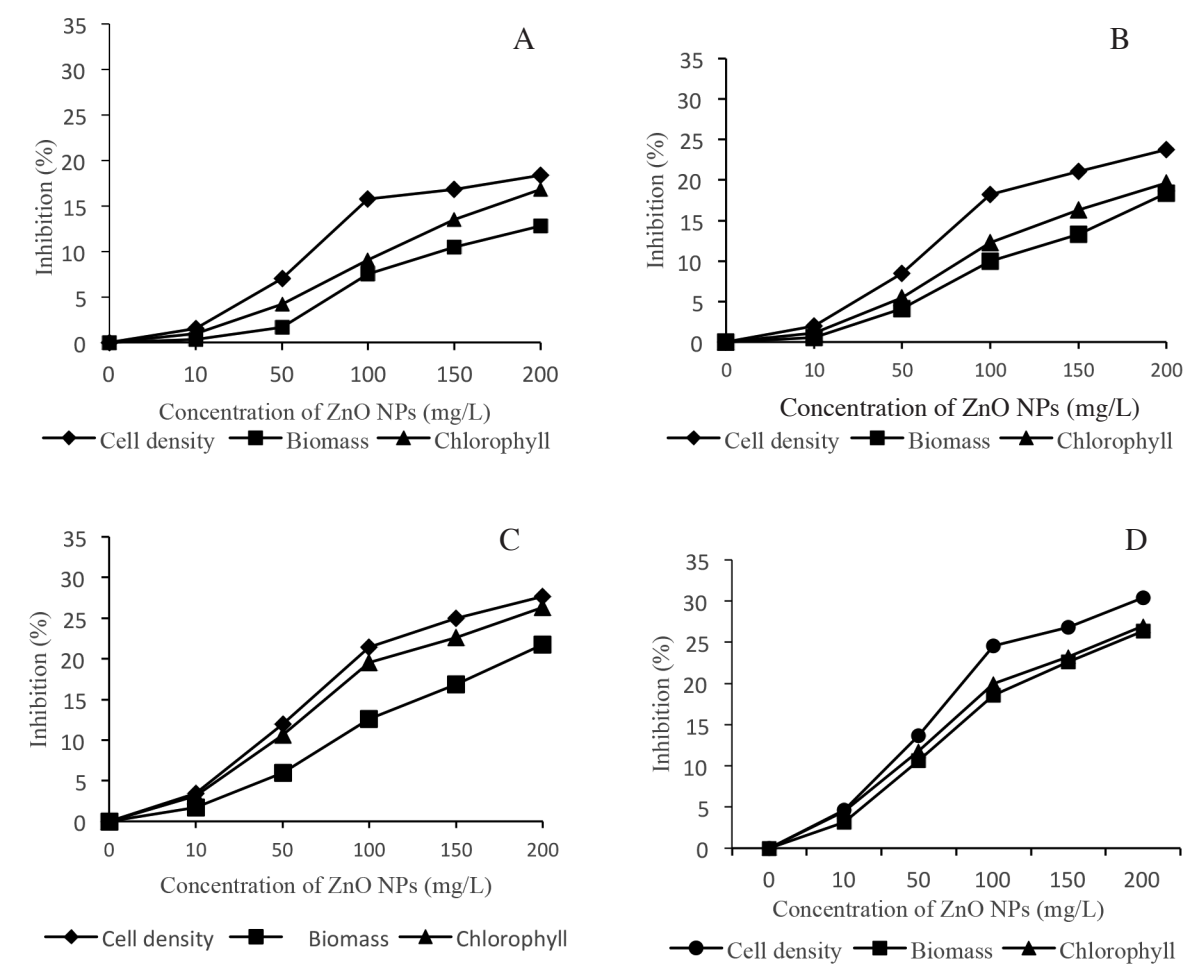

FIGURE 5. Dose response curve of ZnO NPs (10 - $200 \mathrm{mg} / \mathrm{L})$ with the percentage inhibition in cell viability, biomass and chlorophyll fluorescence emission over the different exposure periods of $2 \mathrm{~h}(\mathrm{~A}), 4 \mathrm{~h}(\mathrm{~B}), 8 \mathrm{~h}(\mathrm{C})$ and $12 \mathrm{~h}(\mathrm{D})$

The results obtained here for cytotoxicity studies are in agreement with that obtained in previous studies on Chlorella sp. using titanium dioxide (Iswarya et al. 2015) and nickel oxide (Gong et al. 2011) nanoparticles. The similar outcome of the cytotoxicity effects with $\mathrm{ZnO}$ NPs were reported for other algae species, such as Anabaena flos-aquae (Tang et al. 2013), Pseudokirchneriella subcapitata (Aruoja et al. 2009) and Picochlorum sp. (Hazeem et al. 2016).

\section{CONCLUSION}

The exposure of $\mathrm{ZnO}$ NP to $C$. vulgaris from 2 to $12 \mathrm{~h}$ has led to significant reductions in cell viability, biomass and chlorophyll fluorescence emission. This study confirmed the sensitivity of $C$. vulgaris to the short-term cytotoxicity of $\mathrm{ZnO}$ NPs. Thus, the microalgae $C$. vulgaris may serve as a bioindicator for the presence of $\mathrm{ZnO}$ NPs in the aquatic environment.

\section{ACKNOWLEDGEMENTS}

This project was funded by the Ministry of Education, Malaysia (Grant No. FRGS-1-2014-SG03-INTI-02-1) and Universiti Tunku Abdul Rahman Research Fund (UTARRF), Universiti Tunku Abdul Rahman, Malaysia (Grant No. IPSR/RMC/UTARRF/2016-C1/L3). The authors declare that there is no conflict of interest regarding the publication of this paper.

\section{REFERENCES}

Adams, L., Lyon, D., McIntosh, A. \& Alvarez, P. 2006. Comparative toxicity of nano-scale $\mathrm{TiO} 2, \mathrm{SiO} 2$ and $\mathrm{ZnO}$ water suspensions. Water Science and Technology 54(1112): 327-334.

Aruoja, V., Dubourguier, H.C., Kasemets, K. \& Kahru, A. 2009. Toxicity of nanoparticles of $\mathrm{CuO}, \mathrm{ZnO}$ and $\mathrm{TiO} 2$ to microalgae Pseudokirchneriella subcapitata. Science of the Total Environment 407(4): 1461-1468.

Barhoumi, L. \& Dewez, D. 2013. Toxicity of superparamagnetic iron oxide nanoparticles on green alga Chlorella vulgaris. BioMed Research International 2013: 647974.

Bhuvaneshwari, M., Iswarya, V., Archanaa, S., Madhu, G.M., Suraish Kumar, G.K., Nagarajan, R., Chandrasekaran, N. \& Mukherjee, A. 2015. Cytotoxicity of ZnO NPs towards fresh water algae Scenedesmus obliquus at low exposure concentrations in UV-C, visible and dark conditions. Aquatic Toxicology 162: 29-38.

Brayner, R., Dahoumane, S.A., Yéprémian, C., Djediat, C., Meyer, M., Couté, A. \& Fiévet, F. 2010. ZnO nanoparticles: synthesis, characterization, and ecotoxicological studies. Langmuir 26(9): 6522-6528.

Chen, P., Powell, B.A., Mortimer, M. \& Ke, P.C. 2012. Adaptive interactions between zinc oxide nanoparticles and Chlorella sp. Environmental Science \& Technology 46(21): 1217812185.

Dastjerdi, R. \& Montazer, M. 2010. A review on the application of inorganic nano-structured materials in the modification of textiles: Focus on anti-microbial properties. Colloids and Surfaces B: Biointerfaces 79(1): 5-18. 
Gong, N., Shao, K., Feng, W., Lin, Z., Liang, C. \& Sun, Y. 2011. Biotoxicity of nickel oxide nanoparticles and bio-remediation by microalgae Chlorella vulgaris. Chemosphere 83(4): 510-516.

Hazeem, L.J., Bououdina, M., Rashdan, S., Brunet, L., Slomianny, C. \& Boukherroub, R. 2016. Cumulative effect of zinc oxide and titanium oxide nanoparticles on growth and chlorophyll a content of Picochlorum sp. Environmental Science and Pollution Research 23(3): 2821-2830.

Iswarya, V., Bhuvaneshwari, M., Alex, S.A., Iyer, S., Chaudhuri, G., Chandrasekaran, P.T., Bhalerao, G.M., Chakravarty, S, Raichur, A.M., Chandrasekaran, N. \& Mukherjee, A. 2015. Combined toxicity of two crystalline phases (anatase and rutile) of Titania nanoparticles towards freshwater microalgae: Chlorella sp. Aquatic Toxicology 161: 154-169.

Ji, J., Long, Z. \& Lin, D. 2011. Toxicity of oxide nanoparticles to the green algae Chlorella sp. Chemical Engineering Journal 170(2): 525-530.

Li, X., Zhou, S. \& Fan, W. 2016. Effect of nano-Al2O3 on the toxicity and oxidative stress of copper towards Scenedesmus obliquus. International Journal of Environmental Research and Public Health 13(6): 575.

Miao, A.J., Schwehr, K.A., Xu, C., Zhang, S.J., Luo, Z., Quigg, A. $\&$ Santschi, P.H. 2009. The algal toxicity of silver engineered nanoparticles and detoxification by exopolymeric substances. Environmental Pollution 157(11): 3034-3041.

Moore, M. 2006. Do nanoparticles present ecotoxicological risks for the health of the aquatic environment? Environment International 32(8): 967-976.

Osmond, M.J. \& Mccall, M.J. 2010. Zinc oxide nanoparticles in modern sunscreens: An analysis of potential exposure and hazard. Nanotoxicology 4(1): 15-41.

Popov, A., Priezzhev, A., Lademann, J. \& Myllylä, R. 2005.TiO2 nanoparticles as an effective UV-B radiation skin-protective compound in sunscreens. Journal of Physics D: Applied Physics 38(15): 2564.

Sadiq, I.M., Pakrashi, S., Chandrasekaran, N. \& Mukherjee, A. 2011. Studies on toxicity of aluminum oxide (A12O3) nanoparticles to microalgae species: Scenedesmus sp. and Chlorella sp. Journal of Nanoparticle Research 13(8): 3287-3299.

Shing, W.L., Heng, L.Y. \& Surif, S. 2012. The fluorometric response of cyanobateria to short exposure of heavy metal. Advances in Environmental Biology 6(1): 103-108.

Song, W., Zhang, J., Guo, J., Zhang, J., Ding, F., Li, L. \& Sun, Z. 2010. Role of the dissolved zinc ion and reactive oxygen species in cytotoxicity of $\mathrm{ZnO}$ nanoparticles. Toxicology Letters 199(3): 389-397.

Suman, T., Rajasree, S.R. \& Kirubagaran, R. 2015. Evaluation of zinc oxide nanoparticles toxicity on marine algae Chlorella vulgaris through flow cytometric, cytotoxicity and oxidative stress analysis. Ecotoxicology and Environmental Safety 113: 23-30.
Tang, Y., Li, S., Qiao, J., Wang, H. \& Li, L. 2013. Synergistic effects of nano-sized titanium dioxide and zinc on the photosynthetic capacity and survival of Anabaena sp. International Journal of Molecular Sciences 14(7): 14395 14407.

Wiesner, M.R., Lowry, G.V.,Alvarez, P., Dionysiou, D. \& Biswas, P. 2006. Assessing the risks of manufactured nanomaterials. Environmental Science \& Technology 40(14): 4336-4345.

Xiaoxiao, C., Xing, Z., Rui, L., Hanchao, Y.,Zhisong, L.\& Xu, Y. 2012. Photosynthetic toxicity and oxidative damage induced by nano-Fe3O4 on Chlorella vulgaris in aquatic environment Open Journal of Ecology 2(1): 21-28.

Zhao, J. \& Castranova, V. 2011. Toxicology of nanomaterials used in nanomedicine. Journal of Toxicology and Environmental Health, Part B 14(8): 593-632.

Zhou, H., Wang, X., Zhou, Y., Yao, H. \& Ahmad, F. 2014. Evaluation of the toxicity of $\mathrm{ZnO}$ nanoparticles to Chlorella vulgaris by use of the chiral perturbation approach. Analytical and Bioanalytical Chemistry 406(15): 3689-3695.

Sinouvassane Djearamane \& Poh Foong Lee*

Department of Mechatronics \& Biomedical Engineering

Lee Kong Chian Faculty of Engineering and Science

Universiti Tunku Abdul Rahman

43000 Bandar Sungai Long, Selangor Darul Ehsan

Malaysia

Ling Shing Wong

Faculty of Health and Life Sciences

INTI International University

71800 Nilai, Negeri Sembilan

Malaysia

Yang Mooi Lim

Department of Pre-Clinical Sciences

Faculty of Medicine and Health Sciences

Universiti Tunku Abdul Rahman

43000 Bandar Sungai Long, Selangor Darul Ehsan

Malaysia

*Corresponding author; email: leepf@utar.edu.my

Received: 26 April 2017

Accepted: 12 February 2018 